\title{
PRIVACY IN BRAZIL: ANALYSIS ON THE NEW LAW ON DATA PROTECTION
}

\author{
Eduardo Helfer de Farias and Gabriel Rached \\ Fluminense Federal University \\ Niterói/RJ, Brazil
}

\begin{abstract}
Law $n^{\circ} 13.709 / 18$ established a new legal basis on data protection in Brazil. Inspired by the General Data Protection Regulation of the European Union, this new legislation introduces new concepts, actors and tools to assure the enforceability of rights by the common citizen under Brazilian jurisdiction. However, the impacts this law may produce is still unclear and cannot be foreseen yet. This paper aims to introduce its key topics, discussing how the enforceability issues may arise, given the Brazilian legislation background. As final remarks, some possibilities for the next scenarios in Brazil are also taken into consideration.
\end{abstract}

\section{KEYWORDS}

Brazil, Data Protection, Privacy, LGPD

\section{INTRODUCTION}

Privacy is a right protected by Brazil's Federal Constitution of 1988 in its article 5, X, therefore, its especially protected by the public authorities of the country. In order to enforce this right given the current reality of data sharing, Brazilian National Congress approved on 14 August 2018 the law ${ }^{\mathbf{o}}$ 13.709/18 (Câmara dos Deputados do Brasil, 2018), labelled "Data Protection General Law" ("LGPD" in Portuguese), which was inspired by the European GDPR (Cavalcante, 2018).

This paper will first present the legal aspects of the LGPD's "bill of rights" and then deal with practical issues regarding the enforceability of the law by those subjected to it.

\section{BRAZILIAN DATA PROTECTION LAW: LEGAL ASPECTS}

For the purpose of this paper, it shall be considered only the current status of the LGPD given the changes made by Law $n^{\circ} 13.853$ of 8 July 2019, which is expected to come into force on 16 August 2020. For its understanding, its important to have in mind: (i) who is subjected to the law; (ii) what duties it imposes; (iii) who enforces the law; and (iv) the possible penalties of a violation of the law.

Art. 3 of the LGPD describes that anyone who (i) holds an establishment in Brazil; (ii) offer products or services to the Brazilian market; (iii) or register personal data of people currently in the country; shall be subjected to the law. Its relevant to note that to fall under the scope of the law it doesn't matter the nature of the person (natural person, company or government), the headquarters of the company, the physical location of the data, if it was collected online or offline, or even the nationality of the citizen. If one of these three criteria checks, there is a mandatory duty to follow the law (SILVA et al. 2019). The only exceptions to the scope - as for now - would be the ones described in art. 4 of the LGPD: private and non-economic goals; journalism and arts; public safety; national security; state security; or criminal investigation. There is a partial exception for academic purpose, which still requires the comply with art. 7 and 11 regarding the consent of the owner of the data for its processing, proper classification and guarantees against its misuse. Also, there is a conditional exception regarding data there is exclusively in traffic through the Brazilian borders, not being 
shared, collected or in any way processed within the country, except if the country to which the data is being sent have not a good standard of data protection.

For the purpose of the law, "establishment" can be any representation held within Brazilian borders, regardless if it is for business or not, physical or digital. Also, anyone doing trade with Brazilian market - even if itself is not within the country - shall be subject to the Brazilian law. As for data, there are three classifications for the concept in the art. 5: (i) personal data identifying or capable of identifying a natural person; (ii) sensible data regarding religion, political opinions, healthy, sexual life, genetics, race, among others; (iii) anonymous data over which technology is applied to make sure the person to whom it refers to cannot be identified given the current availability of technology. Important to that data regarding companies itself fall out of the scope of this law, given their protection under the intellectual property laws in Brazil.

Those subject to the LGPD should identify who, in their organization, is the "controller", person or company responsible for making decision about treatment of personal data; the "operator", person or company responsible for executing the orders of the controller; and the "commissionaire", responsible to be a channel of communication between the controller, the owners of the personal data and the Brazilian National Data Protection Agency ("ANPD" in Portuguese), still to be created.

Those who are dealing with the personal data - namely the controller and the operator - should perform duties to both the owners of the data and the ANPD. The main duty would be to get a consent of the data owners for a clear and specific purpose in the terms of art. 7, if the processing is not being due to mandatory reasons listed on the article. Once holding the personal data, the controller and the operator should still meet the demands of art. 18 upon request of the data's owners, namely: (i) confirmation of the existence of data; (ii) access to the data; (iii) correction of incomplete, wrong or outdated data; (iv) anonymization, block or termination of unnecessary or excessive or misused data; (v) portability of the data to another platform or company; (vi) termination of data, except if the company has to comply with regulatory measures, academic research or other cases of the law; (vii) information about with whom the controller shared the data; (viii) information about the possibility of denying consent and its consequences; (ix) enforce the revoke of consent by the data's owner. Upon the purpose for which the data was collected is reached or if so requested by the data's owner, the controller or operator should be able to delete the data in accordance with art. 16, unless the data is anonymized and kept for exclusive use of the controller or to meet some regulatory demands.

The ANPD has regulatory and police authority over personal data protection, being able to apply harsh penalties over those violating the law, may it be a $2 \%$ of the total revenue of the previous year or even 50 millions Brazilian reais. Besides, it may also determine the termination of the data stored, publicize the infraction or, in a less serious case, just give a notification. The ANPD may request the controller to handle reports about the consequences of his operations to the personal data held by him. These reports, in accordance with art. 38, should describe the data held, the methodology used to collect it, the safety measures and the analysis of the controller about possible risks.

After this brief overview of the law, the next chapter shall deal with the practical aspects of its enforceability.

\section{TWO PRACTICAL ISSUES TO COMPLY WITH THE LGPD}

In order to comply with the LGPD there will be two main practical issues to deal with: (i) possible conflicts of interpretation with the GDPR and other legislations; and (ii) the standard proceedings for collecting, managing and terminating personal data in accordance with the possible demands of the data's owner or ANPD.

The scope of application of the law will certainly have conflict with the GDPR, creating situations in which both laws are equally applied. It probably will not be something easily dealt with by the standard conflicts of laws proceedings, given the enforceability issue and the international way through which data flows. Despite the LGPD being inspired in the GDPR, there is no guarantee the country shall follow the interpretation of the GDPR in every case. To address this issue, the LGPD in its art. 33 prevents international data transfer if not to "countries with reasonable data protection standards". What are these "reasonable standards" is open to be defined by the ANPD in accordance with art. 34. This strategy points to Brazil's openness to a global regulation on the issue, as once expressed by former president Dilma Rousseff on her speech to the United Nations (Passarinho, 2013). 
In order to meet the LGPD demands, the data treatment agents must (i) be sure to have the consent of the data's owner; (ii) be aware of the data they possess; (iii) who has access to the data; (iv) terminate the data, once the goal is reached or upon request of the data's owner; and (v) be able to provide full reports of the risks the data is exposed.

Given the objective responsibility of the law, the burden of proving the consent of the owner was well informed falls under the data treatment agents. On this issue, is important to specify what kind of data is being collected - in special if it falls under the sensitive data classification - and explain how, by whom and for which purpose the data will be used. The in-company management of data will imply a big cultural change. For example, many companies are not aware of the data they possess, where and how it is stored, let alone have a clear control of who has or should have access to this data. For example, in a draft of an appeal inside a law firm in favor of a client, documents holding sometimes very sensible data are shared in a chain of emails and forgotten there after the appeal is done. Usually, there is no policy for disposing of the data stored in those emails, even after the purpose is fulfilled or the business relation is terminated. The same goes for former employee's data, or for phone messages and calls, which might be forgotten in old digital or physical archives.

The advised preliminary safeguard measures would be: (i) the adoption of policy of work based on "as-need-to-know" basis, in order to avoid unauthorized access to data; (ii) the programmed anonymization or termination of data after its purpose is served or upon request; (iii) a dashboard capable of effectively receiving the demands of the data's owner or ANPD and quickly granting their request. Other measures might be adopted, case by case, depending on the business model and the evolution of technology.

\section{CONCLUSION}

The Data Protection Law in Brazil is one of the steps in the ongoing changing rules process on the digital world. More and more, the regulation of this market is moving from internet giants to the states. However, despite the technical quality of the writing of the law, it is still unclear if Brazil will take the necessary measures to enforce its rights. It's common in Latin America countries that public policies do not live up to the expectations rose by the laws, due to political, financial or technical contexts. Brazilians define such laws as "lei que não pega", meaning that, despite being formally approved, they will never really come into force.

Given that the issue is still on going and that the law has not came into force yet, it's not possible to make long term predictions. However, the key players to be observed in order to anticipate legal and technical problems regarding the personal data policy in Brazil would be: (i) the ANPD; and (ii) the internet giants.

It is unclear the modus operandi that shall be followed by the ANPD, but it is expected to follow the standard stablished by the GDPR. This tendency is even more visible given the emphasis given by the Brazilian law in international cooperation and international standards. On the other hand, the country has been going through a wave of nationalism and it is not clear if this might affect the future following up of foreign standards. The fact that the law was significantly changed twice before even coming into force reflects not just the controversy of the political spectrum, but also of the issue itself. The composition of the ANPD shall be decisive in observing how this institution will behave.

By the other side, the internet giants such as Google and Facebook have been adapting themselves to the policies of the GDPR and are likely to export these practices to Brazil and other countries. Smaller companies and those whose main business is not directly related to data management shall follow the standard of these two as a precaution, avoiding spending to much energy in something bigger players have already a policy for.

\section{REFERENCES}

Câmara dos Deputados do Brasil. Projeto de Lei $\mathrm{n}^{\circ}$ 4.067/2012. Available in https://www.camara.leg.br/proposicoesWeb/fichadetramitacao?idProposicao=548066 . Date of access: 16 June 2019.

Cavalcante, Sóstenes, 2018. Report of the Project of Law no 4.060/2012. Comissão de Ciência e Tecnologia, Comunicação e Informática da Câmara dos Deputados do Brasil. Brasília, Brasil, Available in https://www.camara.leg.br/proposicoesWeb/prop_mostrarintegra?codteor=1454623\&filename=TramitacaoPRL+1+CCTCI+\%3D\%3E+PL+4060/2012 . Date of access: 16 June of 2019. 
Constituição Federal Da República Federativa Do Brasil de 1988. Available in http://www.planalto.gov.br/ccivil_03/constituicao/constituicao.htm. Date of access: 16 June 2019.

LGPD. Lei Brasileira Sobre Proteção De Dados Pessoais - Lei $\mathrm{n}^{\mathbf{0}}$ 13.709/18. Available at: http://www.planalto.gov.br/ccivil_03/_Ato2015-2018/2018/Lei/L13709.htm. Date of Access: 16 June 2019

Núcleo De Estudos e Pesquisas Do Senado Federal. Sumário executivo da medida provisória $n^{\circ}$ 869. Available at: https://www.congressonacional.leg.br/materias/medidas-provisorias/-/mpv/135062 Date of Access: 16 June 2019

Presidência da República do Brasil. Medida Provisória $\mathrm{n}^{\circ} 869$ de 2018. Available at: https://www.congressonacional.leg.br/materias/medidas-provisorias/-/mpv/135062. Data of Access: 16 June 2019

Passarinho, Natália. Dilma diz na ONU que espionagem fere a soberania e o direito internacional. Published at: http://g1.globo.com/mundo/noticia/2013/09/dilma-diz-na-onu-que-espionagem-fere-soberania-e-direitointernacional.html. Date of Access: 16 June 2019

Silva, Priscilla; Magrani, Eduardo; Affonso, Carlos; Viola, Mário. Introdução à lei brasileira de proteção de dados. Published at: https://mooc.escolavirtual.gov.br/course/view.php?id=3020. Data of Access: 16 June 2019 